\title{
An Efficient and Easy Micro-propagation of Reseda Lutea (Resedaceae) a Rare and Medicinally Valuable Plant of Saudi Arabia
}

\author{
FAHAD AL-QURAINY \\ King Saud University \\ SALEH ALANSI \\ King Saud University \\ SALIM KHAN \\ King Saud University \\ King Saud University \\ AREF AL-SHAMERI \\ King Saud University \\ MOHAMED TARROUM \\ King Saud University \\ ABDEL-RHMAN Z. GAAFAR \\ King Saud University \\ NORA AL-FARRAJ \\ King Saud University
}

MOHAMMAD NADEEM ( $\sim$ mohammadnadeem911@hotmail.com )

\section{Research Article}

Keywords: Micropropagation, Reseda lutea L, in vitro, Organogenesis, Tissue culture, Acclimatization

Posted Date: December 30th, 2021

DOI: https://doi.org/10.21203/rs.3.rs-1127208/v1

License: (1) (1) This work is licensed under a Creative Commons Attribution 4.0 International License. Read Full License 


\section{Abstract}

The goal of this work was to look at the propagation of Reseda lutea L. by organogenesis in tissue culture. Explants from in vitro grown seedlings were taken from the axillary bud. After seven days of culture on MS medium supplemented with $1.0 \mathrm{mg} / \mathrm{BA}$, the adventitious buds developed. After three weeks of culturing on MS medium supplemented with $1.5 \mathrm{mg} / \mathrm{I} \mathrm{BA}$, the maximum multiplication of shoots (16.12 shoots/explant) was discovered, with an average $(7.37 \mathrm{~cm})$ shoots/explant. These shoots were sub-cultured on MS media with varying concentrations of NAA and IBA for root initiation. The MS medium combined with IBA produced the greatest percentage of root development (92\%) and the greatest number of roots (7.37 roots/plant). In MS media supplemented with $0.5 \mathrm{NAA}$, the longest roots $(3.08 \mathrm{~cm})$ were found. After 17 days in a glasshouse, the plantlets were acclimatized in pots containing Peat moss and pearlite, 98 percent of the plantlets were acclimatized. To get a plant in a pot, the complete procedure took about 75 days. The technique proposed could aid in the preservation of the plant both in vivo and in vitro.

\section{Introduction}

Reseda lutea L., a member of the Resedaceae family, is a medicinal plant that is also used for natural dyes, cattle feed, and honey. In the world, there are 12 genera in the Resedaceae family ${ }^{1}$. Nearly 60 species of Reseda may be found all over the world ${ }^{2-4}$. Reseda lutea can be found in southern, central, and western Europe, including Norway, Finland, the United Kingdom, and Sweden; Anatolia and the Mediterranean Basin; Southwest Asia, the former Soviet Union, Chile, Afghanistan, Australia, the United States, New Zealand, and North and South Africa; and Southwest Asia, the former Soviet Union, Chile, Afghanistan, Australia, the United States, and New Zealand ${ }^{5}$. A.G. Miller, $R$. pentagyna Abdallah \& $R$. lutea, $R$. arabica Boiss., $R$. alba, $R$. muricata, $R$. arabica Boiss., $R$. arabica Boiss., $R$. arabica Boiss., $R$. arabica Boiss., R. arabica Boiss., R. arabica Boiss., R. arabica Boiss. In Saudi Arabia, C. Presl, R. sphenocleoides Deflers, and $R$. aucheri Boiss were discovered ${ }^{6}$.

$R$. lutea is a short-lived, biennial, or perennial herbaceous plant that thrives in uncultivated fields, rocky slopes, and roadsides ${ }^{7}$. This plant grows in areas with sandy-clayey-loam and sandy-loam with a pH of medium alkaline to slightly alkaline ${ }^{5}$.

However, Reseda lutea has high valued medicinal plant. It is also used in the carpet industry where it is used together with $R$. luteola as source of a natural dye ${ }^{5,8}$. According to Jablonski, et al. ${ }^{9}$, Reseda lutea is used for the perfection of apiculture. In Iran and Australia, cattle breeders have been using R. Iutea for grazing, as a dry or fresh food source ${ }^{10,11}$. This plant is used to prevent erosion of soil due to its roots that growing fast ${ }^{10}$. Pagnotta, et al. ${ }^{12}$ reported that the $R$. lutea attracts the honeybees and pollinators of wild. Furthermore, $R$. lutea is one of the 10 important plants that feeding Apis mellifera honey bee ${ }^{13}$ as well as $R$. Lutea was known with its cure properties in the pharmacotherapy from ancient times. Therefore, $R$. lutea has recorded to the lists of interesting plant species for ethnopharmacological 
properties ${ }^{14}$. The roots of $R$. lutea, on the other hand, contain diuretic and diarrheal characteristics, according to Bonnier ${ }^{15}$. It is also utilized as an antibacterial and anti-inflammatory agent ${ }^{16}$.

R. lutea is commonly used for tumor reduction, according to Radulovic, et al. ${ }^{17}$.

The preservation of medicinal, imperiled, endangered, and indigenous plant species is critical to humanity's survival. The flora of Saudi Arabia is extremely diverse, with numerous rare and endangered plant species. Furthermore, these plants are under constant threat due to harsh environmental conditions and anthropogenic activity. As a result, the number of vulnerable plant species is growing every year ${ }^{18}$.

Plant tissue culture and biotechnology, on the other hand, offer us with plants that are free of contamination and explants that can be used for biotransformation, propagation, cryopreservation, and germplasm conservation ${ }^{19}$. The tissue culture technique has recently had a large impact on the agricultural industry, and the following are some of the characteristics that demonstrate its relevance 20,21: Plants may be easily transported from the nursery to the field, and this technique can be utilized to improve tolerance to environmental variables and disease. Furthermore, the plants created using this process are disease-free. The propagation of unusual genotypes in the laboratory is possible ${ }^{22}$. The potential of meristematic tissue to generate new branches is exploited in direct organogenesis, and without a callus stage, these plants are assumed to be true-to-type ${ }^{23}$. Several research organizations have worked on organogenesis as a technique of propagation, although this approach is slow and produces few compared to somatic embryogenesis. However, in terms of genetic variants, it is seen as less significant ${ }^{24,25}$.

There is relatively little information available regarding Reseda lutea propagation and multiplication in the field. Furthermore, there may be no information concerning this plant's propagation and regeneration in vitro. As a result, it's critical to look into alternate propagation strategies and the development of this strategy for propagating this crucial plant. To improve the number of in vitro ways that can be used to conserve, mass regenerate, and extend the value of this plant. The major goal of this study was to construct and develop an in vitro propagation strategy for Reseda Lutea plants employing direct organogenesis that was highly repeatable.

\section{Materials And Methods}

The present study was performed at Laboratories of Tissue Culture and Molecular Biology, Botany and Microbiology Department, Science Faculty, King Saud University, Riyadh, Saudi Arabia.

\section{Plant material}

The shoots with flowers of the plant Reseda lutea were obtained from an overland population in Saudi Arabia's Tabuk region and authenticated by the Botany and Microbiology Department of King Saud University's Science Faculty. The seeds of Reseda lutea were removed from the flowers and dried for 96 
hours in an open clean petri dish at room temperature, after which they were stored in a clean covered tube in the refrigerated at $4^{\circ} \mathrm{C}$ for four months.

\section{Seeds Germination}

The seeds of Reseda lutea were taken out from the refrigerator and washed for 10 minutes in running tap water containing a few drops of tween 80. Furthermore, the seeds were sterilized for 10 minutes in the Laminar Air Cabinet under aseptic conditions using 15\% sodium hypochlorite and moderate shaking at regular intervals. To remove the bleach, the seeds were rinsed three times with double distilled water for five minutes each time. Ten seeds of $R$. lutea were cultured on agar MS media and incubated in the culture room at $25^{\circ} \mathrm{C}$ in the dark until seedlings with small four-leaved stages appeared (after one month, only three seeds were germinated). After that, we chose one plantlet as the explant source.

\section{Media of culture}

We employed the ready MS medium with vitamins (Sigma-Aldrich Chemicals Company) in this investigation, which comprises all nutrient elements ${ }^{26}$. (micro and macronutrients). All vitamins $(0.5$ $\mathrm{mg} / \mathrm{l}$ Nicotinic acid, $0.5 \mathrm{mg} / \mathrm{l}$ Pyridoxine $\mathrm{HCl}$, Myo-inositol, $2 \mathrm{mg} / \mathrm{l}$ Glycine, $0.1 \mathrm{mg} / \mathrm{l}$ Thiamine HCL) are also included.

The sucrose was added at a rate of $20 \mathrm{~g} / \mathrm{l}$. Plant growth regulators were added as needed depending on the stage of propagation. The $\mathrm{pH}$ ( $\mathrm{pH}$ meter 526 multical ${ }^{\circledR}$ WTW) was adjusted to 5.6 using $0.1 \mathrm{~N} \mathrm{NaOH}$ or $0.1 \mathrm{~N} \mathrm{HCl}$, and $7 \mathrm{~g} / \mathrm{l}$ Agar was added to solidify the MS media. The MS medium was autoclaved for 20 minutes at $121^{\circ} \mathrm{C}$ and $1 \times 105 \mathrm{~Pa}$ to sterilize it $(1.1 \mathrm{~kg} \mathrm{~cm}-2)$.

\section{Shoot induction}

Explants for shoot induction were the nodal segment of shoots (axillary bud) from Reseda lutea seedlings cultivated in vitro (direct organogenesis). The nodal segments were grown on MS agar media with varied PGR concentrations $(0.0,0.1,0.5$, and $1.0 \mathrm{mg} / \mathrm{l} \mathrm{BA})$. For three weeks, cultures were incubated in the dark at $27 \pm 2{ }^{\circ} \mathrm{C}$. The number of adventitious buds was calculated after one month of culture and the number of induced adventitious buds was measured by daily monitoring of the cultures.

\section{Shoot multiplication}

The MS agar media supplemented with varied doses of $2 \mathrm{ip}(0,0.1,0.5,1.5$, and $5 \mathrm{mg} / \mathrm{L})$ and concentrations of cytokinin BA $(0,0.1,0.5,1.5$, and $5 \mathrm{mg} / \mathrm{L})$ were employed in this work. The adventitious buds were separated into tiny lumps, each comprising at least two buds, and grown in Magenta vessels on MS media. The cultures were incubated for two weeks at $27 \pm 2^{\circ} \mathrm{C}$. The number of multiplexed shoots was counted after three weeks of cultivation. In addition, the lengths of the shoots were calculated.

\section{Rooting}


Individually, multiplied and propagated shoots $(2.0-3 \mathrm{~cm})$ with at least 2-3 leaves were detached and cultivated on a fresh MS medium with varied concentrations of Indole-3-butyric acid (IBA) and aNaphthaleneacetic acid (NAA) $(0.0,0.1,0.5,1.5,3.0 \mathrm{mg} / \mathrm{l})$. For four weeks, the cultures were incubated at $27 \pm 2^{\circ} \mathrm{C}$. The proportion of rooted plantlets, the number of roots per plantlet, and the length of roots were all measured on a daily basis while the cultures were monitored.

\section{Acclimatization}

Plantlets with good roots, a height range of (5-7) $\mathrm{cm}$, and at least four leaves were chosen for acclimatization. To remove any trace of media adhering from the root system, these plantlets were rinsed with tap water. The plantlets were transplanted into containers containing a sterilized soil combination of peat-moss and perlite (2:1). The plantlets were covered with a transparent plastic bag until the high humidity was maintained, then the cover was removed for half an hour every day for one week, then the length of cover removal was gradually increased until the cover was totally removed at the end of the second week. Watering was done every three days or as needed depending on the potting mix quality.

\section{Culture condition}

The cultures were incubated in a culture room set at $27 \pm 2^{\circ} \mathrm{C}$, under photoperiod of $8 \mathrm{~h}$ dark/ $16 \mathrm{~h}$ light and light intensity $\left(3,000 \mathrm{Im} \mathrm{m}^{-2}\right)$, the relative humidity was maintained at $60 \%$.

\section{Design of experimental and statistical analysis}

The trials were designed and carried out as factorial experiments, which were entirely randomized. The tests were carried out in triplicate for each treatment. The statistical analysis was carried out with the use of the SPSS software program (version 11, SPSS Inc., Chicago, USA) and a one-way analysis of variance (ANOVA) Duncan's test was used to compare mean averages of the main effects at the P 0.05 level (results were represented as means $\pm \mathrm{SE}$ ).

\section{Results And Discussion}

\section{Shoot induction}

After three weeks of growth on MS media, the effect of various concentrations of BA $(0.0,0.1,0.5$, and 1.0 $\mathrm{mg} / \mathrm{l})$ on the induction of adventitious buds from $R$. lutea explants was studied. Table 1 and Fig. $1 \mathrm{~A}$ indicate that there is a direct link between the number of buds and the concentration of $B A$, with the number of buds increasing up to $1 \mathrm{mg} / \mathrm{I} B$. Following that, the number of buds dropped as the BA concentration grew, despite the fact that the PGR concentration increased by $1.5 \mathrm{mg} / \mathrm{L}$. However, the optimal BA concentration employed in this investigation was $1.0 \mathrm{mg} / \mathrm{l}$, which produced the most buds (6.750.35 buds/explant) with a significant difference compared to the other treatments. The findings of this investigation corroborate previous findings ${ }^{27}$ Passiflora mollussima, Passiflora mollussima, 
Passiflora mollussi ${ }^{28}$ Mentha viridis, Mentha viridis, Mentha viridis ${ }^{29}$ Rubia cardifolia is a kind of Rubia. Kumar et al. ${ }^{30}$ Trichosanthes dioica, ${ }^{31}$ Strobilanthes tonkinensis, and Reseda pentagyna ${ }^{19}$.

Table 1

Effect of various concentration of BA on the induction of adventitious buds

\begin{tabular}{|ll|}
\hline Concentration of BA & Number of adventitious buds Mean \pm SE \\
\hline $0.0 \mathrm{mg} / \mathrm{l}$ & $0.00 \pm 0.00 \mathrm{a}$ \\
\hline $0.1 \mathrm{mg} / \mathrm{l}$ & $2.75 \pm 0.36 \mathrm{~b}$ \\
\hline $0.5 \mathrm{mg} / \mathrm{l}$ & $4.62 \pm 0.29 \mathrm{c}$ \\
\hline $1.0 \mathrm{mg} / \mathrm{l}$ & $6.75 \pm 0.35 \mathrm{~d}$ \\
\hline $1.5 \mathrm{mg} / \mathrm{l}$ & $5.75 \pm 0.31 \mathrm{e}$ \\
\hline $\begin{array}{l}\text { *Data that hold the same alphabets are not significantly different, according to the test of Duncan at } \\
\text { level }(p<0.05) .\end{array}$ \\
\hline
\end{tabular}

The explants cultivated in MS media without PGRs, on the other hand, showed no reaction. The phytohormone BA is known to stimulate adventitious buds. According to Jun-jie, et al. ${ }^{32}$, different internal factors influence cell activities during adventitious buds regeneration, one of which is cytokinins, which could explain changes in internal structure and chemical nature. However, the BA's exact mechanism of action is unknown ${ }^{33}$. Furthermore, AlAnsi, et al. ${ }^{34}$ observed that adding cytokinins to the MS medium activates the adventitious buds by enhancing DNA replication, which leads to cell division. It is worth mentioning that during the stage of adventitious buds break, in the first week we saw little of callus formed on the edge of the cut surface (Fig. 1A).

\section{Shoot Multiplication}

To optimize the concentration of BA and 2iP for $R$. lutea shoot multiplications and plant growth, the adventitious buds were subcultured on MS media supplemented with two distinct phytohormones (BA or $2 \mathrm{iP})$ at varied concentrations $(0.0,0.1,0.5,1.5,5 \mathrm{mg} / \mathrm{l})$. The data in Table (2) and (Fig. 1) reveal that BA, as well as 2ip, have a substantial effect.

The highest number of shoots (16.12 shoots/explant) is induced at $1.5 \mathrm{mg} / \mathrm{l} \mathrm{BA}$, although the highest number of shoots (13.87 shoots/explant) is generated at $5.0 \mathrm{mg} / \mathrm{l} \mathrm{BA}$ (2ip). Up to $1.5 \mathrm{mg} / \mathrm{l}$ of BA on the MS medium, the concentrations of BA were directly connected to the number of shoots as well as the length of plantlets (Fig. $1 \mathrm{f} \mathrm{\&} \mathrm{h).} \mathrm{The} \mathrm{quantity} \mathrm{and} \mathrm{length} \mathrm{of} \mathrm{plantlets} \mathrm{decreased} \mathrm{as} \mathrm{the} \mathrm{concentration} \mathrm{of} \mathrm{BA}$ rose up to $5 \mathrm{mg} / \mathrm{I}$ (Table 2). As a result, at the same concentration of BA $(1.5 \mathrm{mg} / \mathrm{l})$, the largest number of multiplied shoots $(16.12 \pm 0.54)$ and shoot length $(7.37 \pm 0.16)$ were observed. In the case of $2 i p$, the maximum number of multiple shoots $(13.87 \pm 0.51)$ was obtained at the concentration of $5 \mathrm{mg} / \mathrm{l} 2 \mathrm{ip}$ (Fig. $1 \mathrm{~g})$, while the maximum length of shoots $(6.02 \pm 0.28)$ was obtained at the concentration of (1.5 $\mathrm{mg} / \mathrm{l})$ 2ip. It's worth noting that the plantlets' shoots grew quickly in all of the concentrations employed in 
this investigation, therefore the data were recorded after two weeks of culturing. In addition, there was a substantial difference between all of the treatments. These findings are consistent with those of our previous study on Reseda pentagyna ${ }^{19}$, as well as Jose and Satheeshkumar ${ }^{35}$, who found that $5 \mathrm{mg} / \mathrm{L}$ of $2 \mathrm{iP}$ offered the greatest outcomes in date palm in their study on 0. mungos $^{36}$. Our findings, on the other hand, contradicted those of Al-Mayahi, et al. ${ }^{37}$, who discovered that a concentration of $4 \mathrm{mg} / \mathrm{L}$ of 2iP was optimal in the multiplication stage of date palm.

Table 2

Effect of various concentrations of $\mathrm{AB}$ and $2 \mathrm{iP}$ on multiplication of indirect buds of $R$. Lutea.

\begin{tabular}{|c|c|c|}
\hline Con. of BA and 2ip & Average no. of multiple buds $\pm S E$ & Average shoot length \pm SE \\
\hline $0.0 \mathrm{BA} \mathrm{mg} / \mathrm{l}$ & $3.75 \pm 0.45 a^{*}$ & $3.06 \pm 0.23 \mathrm{a}$ \\
\hline $0.1 \mathrm{BA} \mathrm{mg} / \mathrm{l}$ & $6.00 \pm 0.42 b$ & $5.25 \pm 0.25 \mathrm{c}$ \\
\hline $0.5 \mathrm{BA} \mathrm{mg} / \mathrm{l}$ & $13.75 \pm 0.77 f$ & $6.62 \pm 0.40 \mathrm{~d}$ \\
\hline 1.5 BA mg/l & $16.12 \pm 0.54 \mathrm{j}$ & $7.37 \pm 0.16 \mathrm{e}$ \\
\hline $5 \mathrm{BA} \mathrm{mg} / \mathrm{l}$ & $9.87 \pm 0.47 d$ & $4.91 \pm 0.22 b c$ \\
\hline $0.12 \mathrm{ip} \mathrm{mg/l}$ & $5.00 \pm 0.46 \mathrm{ab}$ & $4.56 \pm 0.22 \mathrm{bc}$ \\
\hline 0.5 2ip mg/l & $7.62 \pm 0.41 \mathrm{c}$ & $5.11 \pm 0.12 \mathrm{c}$ \\
\hline 1.5 2ip mg/l & $11.87 \pm 0.51 \mathrm{e}$ & $6.02 \pm 0.28 \mathrm{~d}$ \\
\hline 5 2ip mg/l & $13.87 \pm 0.51 \mathrm{~d}$ & $4.18 \pm 0.20 \mathrm{~b}$ \\
\hline
\end{tabular}


Table 3

Effect of various concentrations $(0.0,0.0 .5,1.5$, and $3 \mathrm{mg} / \mathrm{L})$ of PGRs (IBA and NAA) on the number and length of roots formed (Mean $\pm \mathrm{SE}$ ) of $R$. lutea.

\begin{tabular}{|c|c|c|c|c|c|}
\hline $\begin{array}{l}\text { Con. of } \\
\text { (PGRs) } \\
\mathrm{mg} / \mathrm{L}\end{array}$ & $\begin{array}{l}\text { No. of } \\
\text { Roots/plantlet } \\
\pm \text { SE }\end{array}$ & $\begin{array}{l}\text { Root length } \\
\text { (cm) } \pm S E\end{array}$ & $\begin{array}{l}\text { Rooting } \\
\%\end{array}$ & $\begin{array}{l}\text { Average no. of } \\
\text { roots/plantlet } \pm S E\end{array}$ & $\begin{array}{l}\text { Average of root } \\
\text { length }(\mathrm{cm})(\mathrm{A})\end{array}$ \\
\hline $\begin{array}{l}\text { (MS) } \\
\text { Control }\end{array}$ & $3.06 \pm 0.27 a^{*}$ & $0.67 \pm 0.25 \mathrm{a}$ & $10 \%$ & $0.612 \pm 0.175 a$ & $0.675 \pm 0198 a$ \\
\hline $\begin{array}{l}0.1 \mathrm{IBA} \\
\mathrm{mg} / \mathrm{l}\end{array}$ & $5.25 \pm 0.24 \mathrm{~d}$ & $\begin{array}{l}1.63 \pm 0.07 \\
a b\end{array}$ & $72 \%$ & \multirow[t]{4}{*}{$2.500 \pm 0.212 b$} & \multirow[t]{4}{*}{$2.140 \pm 0.110 \mathrm{~b}$} \\
\hline $\begin{array}{l}0.5 \mathrm{IBA} \\
\mathrm{mg} / \mathrm{l}\end{array}$ & $6.62 \pm 0.41 \mathrm{e}$ & $\begin{array}{l}2.33 \pm 0.11 \\
\text { bc }\end{array}$ & $87 \%$ & & \\
\hline $\begin{array}{l}1.5 \mathrm{IBA} \\
\mathrm{mg} / \mathrm{l}\end{array}$ & $7.37 \pm 0.15 f$ & $2.92 \pm 0.15 \mathrm{c}$ & $92 \%$ & & \\
\hline 3 IBA mg/l & $4.91 \pm 0.19 b c$ & $\begin{array}{l}1.66 \pm 0.11 \\
a b\end{array}$ & $79 \%$ & & \\
\hline $\begin{array}{l}0.1 \mathrm{NAA} \\
\mathrm{mg} / \mathrm{l}\end{array}$ & $4.56 \pm 0.17 b c$ & $1.81 \pm 0.97 b$ & $35 \%$ & \multirow[t]{4}{*}{$3.125 \pm 0.410 b$} & \multirow[t]{4}{*}{$2.378 \pm 0.214 b$} \\
\hline $\begin{array}{l}0.5 \mathrm{NAA} \\
\mathrm{mg} / \mathrm{l}\end{array}$ & $6.02 \pm 0.26 \mathrm{e}$ & $3.08 \pm 0.14 \mathrm{c}$ & $90 \%$ & & \\
\hline $\begin{array}{l}1.5 \mathrm{NAA} \\
\mathrm{mg} / \mathrm{l}\end{array}$ & $5.11 \pm 0.13 d$ & $\begin{array}{l}2.23 \pm 0.09 \\
b c\end{array}$ & $80 \%$ & & \\
\hline 3 NAA mg/l & $4.18 \pm 0.19 b$ & $\begin{array}{l}2.37 \pm 0.91 \\
\text { bc }\end{array}$ & $85 \%$ & & \\
\hline
\end{tabular}

\section{Rooting}

Any in vitro plant regeneration protocol must include a roots system that is both efficient and effective ${ }^{38}$. As a result, the influence of two auxins at varying concentrations on root induction and growth was investigated. The rooting of $R$. lutea plantlets regenerated through organogenesis was investigated. In general, the findings in Table (3) reveal that the IBA and NAA have no significant effect on the quantity and length of roots.

On the other hand, there was a substantial difference in the number and length of roots between the phytohormone utilized in this study and MS media (control). The NAA, on the other hand, produced a higher mean number of roots $(3.125 \pm 0.410)$ and longer roots $(2.378 \pm 0.214 \mathrm{~cm})$ than the IBA, which produced a mean number of roots $(2.500 \pm 0.212)$ and root length $(2.140 \pm 0.110 \mathrm{~cm})$ with no significant effect. Our findings contradict those of Wang, et al. ${ }^{39}$, who claimed that the IBA was the best for rooting in Pseudostellaria heterophylla shoots. In terms of the influence of different concentrations of IBA or NAA 
on the number and length of the roots, the data in Table (3) reveals that varying concentrations of IBA or NAA have a substantial effect on the number and length of the roots (Fig. 2).

Furthermore, the optimum IBA concentration was $1.5 \mathrm{mg} / \mathrm{l}$, which produced the most roots $(7.37 \pm 0.15$ /explant), the longest roots $(2.92 \pm 0.15 \mathrm{~cm})$, and the highest percentage of rooting $(92 \%)$.

(Fig. 2d). The optimal NAA concentration was $0.5 \mathrm{mg} / \mathrm{l}$, which produced the most roots $(6.02 \pm 0.26)$ and the longest roots $(3.08 \pm 0.14 \mathrm{~cm}$ ), as well as the highest percentage of rooting (90\%). (Fig, $2 \mathrm{c}$ ). Our findings are consistent with those of Abbas, et al. ${ }^{36}$, who found that $0.5 \mathrm{mg} / \mathrm{L}$ NAA was the optimum for roots in date palm shoots regenerated from adventitious buds. However, Al-Qurainy, et al. ${ }^{38}$ reported that when Tamarix nilotica shoots were cultured on MS medium with $100 \mathrm{M}$ IBA for 5,10 , and 15 days, they were rooted. $1.5 \mathrm{mM}$ IBA was shown to be the best for rooting $R$. pentagyna, according to Al-Qurainy, et al. ${ }^{19}$. Auxins (especially IBA) play a substantial role in root stimulation for Turnera ulmifolia and $R$. pentagyna shoots regenerated in vitro, according to Shekhawat, et al. ${ }^{40}$ and Al-Qurainy, et al. ${ }^{19}$. IBA was also utilized to root Trichosanthes dioica shoots in vitro ${ }^{30}$ and Strobilanthes tonkinensis shoots in vitro 30,31 . For acclimation, thirty rooted plantlets with five to seven complete leaves were chosen, then cleaned of traces of agar and put in pots containing peat-moss and perlite (2:1) for seventeen days. These plantlets were effectively acclimatized, with a survival rate of 98 percent (Fig. 2f, g, and h).

\section{Conclusions}

The current study described a successful technique for $R$. lutea shoot regeneration via direct organogenesis that is simple, quick, and adaptable. As a result, the methodology devised could aid in plant conservation and regeneration. It could also be employed in student practical studies, genetic investigations, and the extraction of active ingredients for medications from in vitro cultures.

\section{Declarations}

\section{Acknowledgment}

This Project was funded by the National Plan for Science, Technology and Innovation (MAARIFAH), King Abdulaziz City for Science and Technology, Kingdom of Saudi Arabia, Award Number (14BI0724-02).

Legal statement: The plant materials utilized in this investigation were collected in accordance with applicable institutional, national, and international norms and legislation. Botany and Microbiology Department (Garden and Herbarium Unit), College of Science, King Saud University (KSU) gathered $R$. Iutea seeds and supplied them with complete authority to collect plant materials by accepting the terms and conditions of national and international standards.

\section{References}


1 Christenhusz, M. J. \& Byng, J. W. The number of known plants species in the world and its annual increase. Phytotaxa 261, 201-217 (2016).

2 Davis, P., Mill, R. \& Tan, K. Flora of Turkey and the East Aegean Islands, Vol 10 (Suppl.) Edinburgh Univ. Press, Edinburgh, Scotland. (1988).

3 Davis, P. H. Flora of Turkey and the East Aegean Island. Edinburgh Univ. Press, Edinburgh, Scotland. 1 (1965).

4 ÖZHATAY, N., KÜLTÜR, Ş. \& AKSOY, N. Check-list of additional taxa to the supplement flora of Turkey II. Turkish Journal of Botany 23, 151-170 (1999).

5 DOĞAN, Y. A study on the autecology of Reseda lutea L.(Resedaceae) distributed in Western Anatolia. Turkish Journal of Botany 25, 137-148 (2001).

6 Chaudhary, S. A. Resedaceae. In: Chaudhary, S. (Ed.), Flora of the Kingdom of Saudi Arabia, illustrated. Vol. 1 536-543 (Ministry of Agriculture \& Water, National Agriculture and Water Research Center, National Herbarium, 1999).

7 Dogan, Y., Mert, H. \& Akcan, K. Anatomical studies of Reseda lutea (Resedaceae). Phytologia Balcan 14, 91-95 (2008).

$8 \quad$ Anonymous. Dyeing of wool fibers with dyes obtained from plants. First edn, (General Directorate of Small Arts, Industrial Zones and Sites, Ministry of Industry and Trade, 1991).

9 Jablonski, B., Koltowski, Z. \& Dabska, B. Nectar secretion and honey efficiency of important plants in Poland conditions, Part 7. J. Apicult. Sci 36, 54-64 (1992).

10 Heap JW, M. W., PM Kloot. Reseda lutea L. - In: Groves, R.H., Shepherd, R.C.H. \& Richardson, R.G. (eds), The Biology of Australian Weeds. . Vol. 1 (R.G. and F.J. Richardson 1995).

11 Moghaddam, M. Reseda lutea: a multipurpose plant for arid and semiarid lands. Rangeland Ecology \& Management/Journal of Range Management Archives 30, 71-72 (1977).

12 Pagnotta, E. et al. Glucosinolates in Reseda lutea L.: Distribution in plant tissues during flowering time. Biochemical Systematics and Ecology 90, 104043 (2020).

13 Wood, T. J., Holland, J. M. \& Goulson, D. Pollinator-friendly management does not increase the diversity of farmland bees and wasps. Biological Conservation 187, 120-126 (2015).

14 Cakilcioglu, U., Khatun, S., Turkoglu, I. \& Hayta, S. Ethnopharmacological survey of medicinal plants in Maden (Elazig-Turkey). J Ethnopharmaco/ 137, 469-486, doi:10.1016/j.jep.2011.05.046 (2011).

15 Bonnier, G. (Belin, 1934). 
16 Bremner, P. et al. Assessing medicinal plants from South-Eastern Spain for potential antiinflammatory effects targeting nuclear factor-Kappa B and other pro-inflammatory mediators. $J$ Ethnopharmacol 124, 295-305, doi:10.1016/j.jep.2009.04.035 (2009).

17 Radulovic, N. S., Zlatkovic, D. B., Ilic-Tomic, T., Senerovic, L. \& Nikodinovic-Runic, J. Cytotoxic effect of Reseda lutea L.: A case of forgotten remedy. J Ethnopharmacol 153, 125-132, doi:10.1016/j.jep.2014.01.034 (2014).

18 Khan, S., Al-Qurainy, F. \& Nadeem, M. Biotechnological approaches for conservation and improvement of rare and endangered plants of Saudi Arabia. Saudi J Biol Sci 19, 1-11, doi:10.1016/j.sjbs.2011.11.001 (2012).

19 Al-Qurainy, F. et al. Rapid plant regeneration, validation of genetic integrity by ISSR markers and conservation of Reseda pentagyna an endemic plant growing in Saudi Arabia. Saudi J Biol Sci 25, 111116, doi:10.1016/j.sjbs.2017.07.003 (2018).

20 Jain, S. M. Recent advances in date palm tissue culture and mutagenesis. Acta horticulturae 736, 205-211 (2007).

21 Zaid, A. \& De Wet, P. Chapter V Date Palm Propagation. FAO Plant Production and Protection Papers, 74-106 (1999).

22 Ferry, M. in Date Palm Biotechnology 15-28 (Springer, 2011).

23 Kunert, K., Baaziz, M. \& Cullis, C. Techniques for determination of true-to-type date palm (Phoenix dactylifera L.) plants: a literature review. Emirates Journal of Food and Agriculture, 1-16 (2003).

24 Al-Khateeb, A. A. Regulation of in vitro bud formation of date palm (Phoenix dactylifera L.) cv. Khanezi by different carbon sources. Bioresour Technol 99, 6550-6555, doi:10.1016/j.biortech.2007.11.070 (2008).

25 Taha, H., Bekheet, S. \& Saker, M. Factors affecting in vitro multiplication of date palm. Biologia plantarum 44, 431-433 (2001).

26 Murashige, T. \& Skoog, F. A revised medium for rapid growth and bio assays with tobacco tissue cultures. Physiologia plantarum 15, 473-497 (1962).

27 Johnson, M., Yasmin, N., Sonali, D. \& Rajasekara, P. The role of cytokinin and auxin in organogenesis of Passiflora mollissima and evaluation of biochemical changes using isozyme and protein profiles. Ethiopian Journal of Science and Technology 4, 27-36 (2007).

28 Raja, H. D. \& Arockiasamy, D. In vitro Propagation of Mentha viridis L. from Nodal and Shoot tip Explants. Plant Tissue Culture and Biotechnology 18, 1-6 (2008). 
29 Ghatge, S., Kudale, S. \& Dixit, G. An improved plant regeneration system for high frequency multiplication of Rubia cordifolia L.: a rare medicinal plant. Asian J. Biotechno/ 3, 397-405 (2011).

30 Kumar, S., Singh, H., Pandey, V. \& Singh, B. In vitro multiplication of pointed gourd (Trichosanthes dioica) through nodal explant culture, and testing the genetic fidelity of micropropagated plants using RAPD markers. (2016).

31 Srikun, N. In vitro propagation of the aromatic herb Strobilanthes tonkinensis Lindau. Agriculture and Natural Resources 51, 15-19 (2017).

32 Jun-jie, Z. et al. An efficient micropropagation protocol for direct organogenesis from leaf explants of an economically valuable plant, drumstick (Moringa oleifera Lam.). Industrial Crops and Products 103, 59-63 (2017).

33 Montalban, I. A., Novak, O., Rolcik, J., Strnad, M. \& Moncalean, P. Endogenous cytokinin and auxin profiles during in vitro organogenesis from vegetative buds of Pinus radiata adult trees. Physiol Plant 148, 214-231, doi:10.1111/j.1399-3054.2012.01709.x (2013).

34 AlAnsi, S. et al. An efficient micropropagation protocol via indirect organogenesis from callus of economically valuable crop date palm (Phloenix dactylifera L.) Cultivars "Sagai and Khalas". Pak. J. Bot 52, 2021-2030 (2020).

35 Jose, B. \& Satheeshkumar, K. In vitro mass multiplication of Ophiorrhiza mungo Linn. Indian J Exp Biol 42, 639-642 (2004).

36 Abbas, M. F., Jasim, A. M. \& Saheem, A. A. Effect of plant growth regulators on adventitious buds formation from date palm callus (Phoenix dactylifera L.) cv. Barhee in vitro. Basrah Journal For Date Palm Research 7, 32-50 (2008).

37 Al-Mayahi, A., Attaha, A. \& Abbas, J. Micropropagation of four rare cultivars of date palm (Phoenix dactylifera L.) by adventitious shoot induction. basrah journal of science 29, 72-94 (2011).

38 Al-Qurainy, F., Nadeem, M., Khan, S., Tarroum, M. \& Alansi, S. Development of high efficiency micropropagation protocol for Tamarix Nilotica Ehrenb with valued medicinal properties. Pak. J. Bot 47, 2355-2359 (2015).

39 Wang, F., Xin, X., Wei, H., Qiu, X. \& Liu, B. In vitro regeneration, ex vitro rooting and foliar stoma studies of Pseudostellaria heterophylla (Miq.) Pax. Agronomy 10, 949 (2020).

40 Shekhawat, M., Kannan, N., Manokari, M. \& Ramanujam, M. An efficient micropropagation protocol for high-frequency plantlet regeneration from liquid culture of nodal tissues in a medicinal plant, Turnera ulmifolia L. Journal of Sustainable Forestry 33, 327-336 (2014). 


\section{Figures}
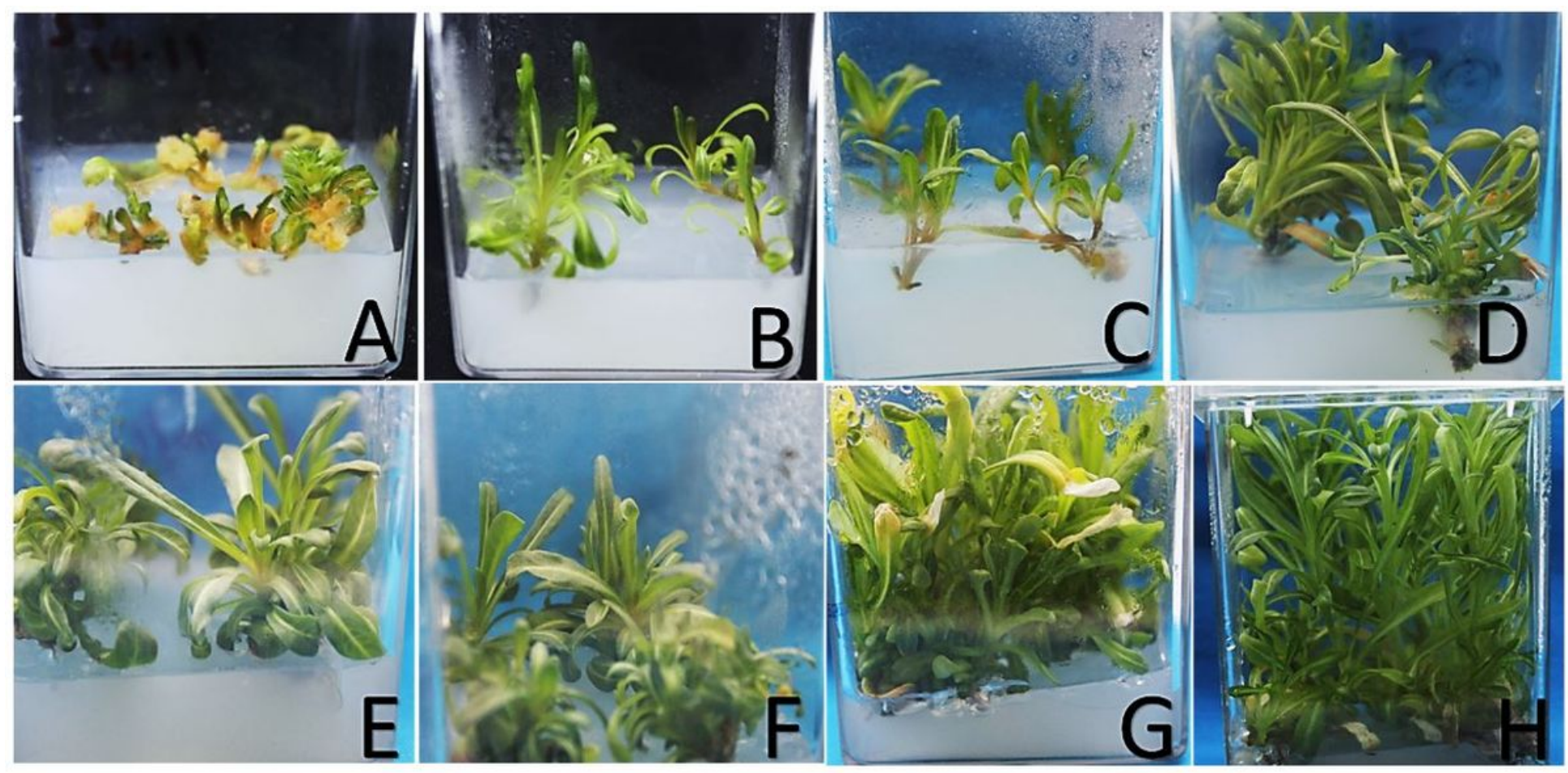

Figure 1

In vitro multiplication of Reseda lutea A: Adventitious bud induction on MS medium supplemented with $1.0 \mathrm{mg} / \mathrm{I}$ of BA, B and C: Individual shoots cultured on MS medium supplemented with BA for multiplication, D: Shoots multiplication on MS medium containing $0.1 \mathrm{mg} / \mathrm{l}$ of BA, E: Shoots multiplication on MS medium containing $0.1 \mathrm{mg} / \mathrm{l}$ of 2iP, F: Shoots multiplication on MS medium containing $0.5 \mathrm{mg} / \mathrm{I}$ of BA, G: Shoots multiplication on MS medium containing $5 \mathrm{mg} / \mathrm{l}$ of $2 \mathrm{iP}, \mathrm{H}$ : Shoots multiplication on MS medium containing $1.5 \mathrm{mg} / \mathrm{l}$ of BA 

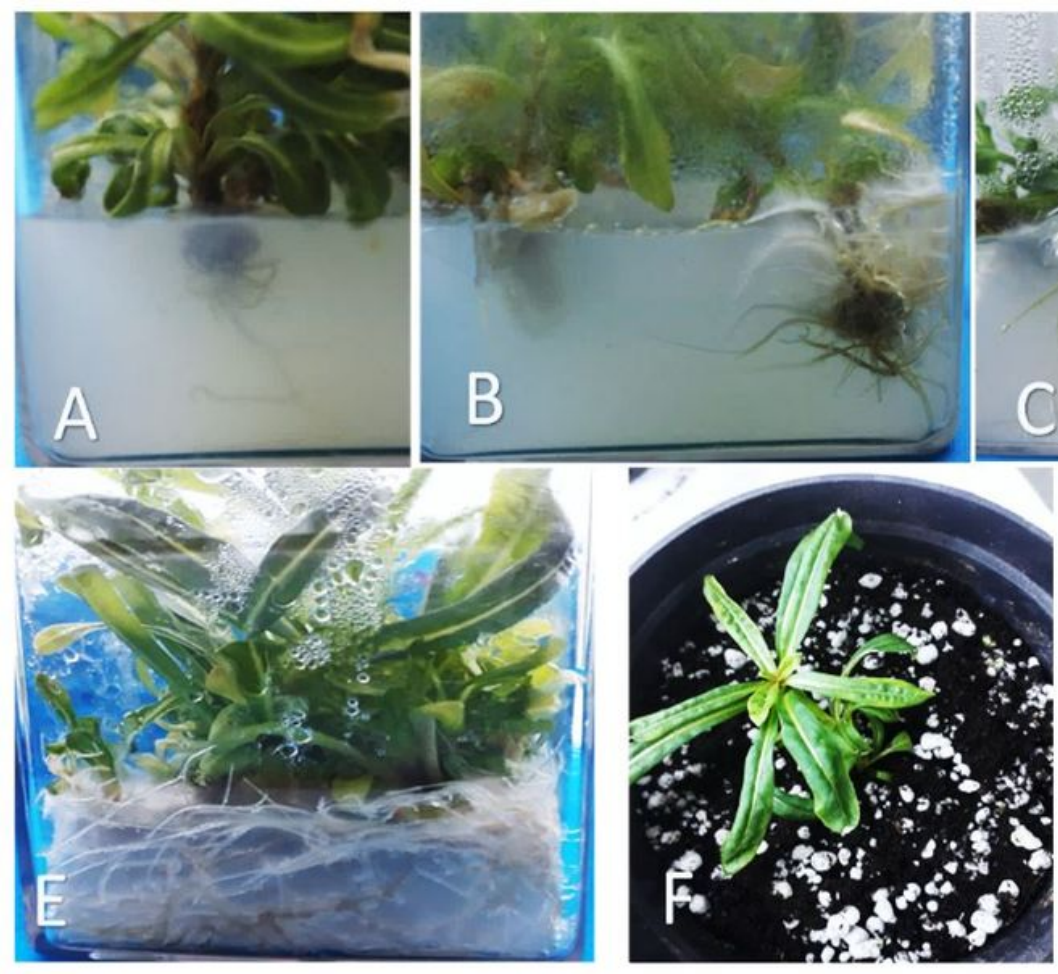
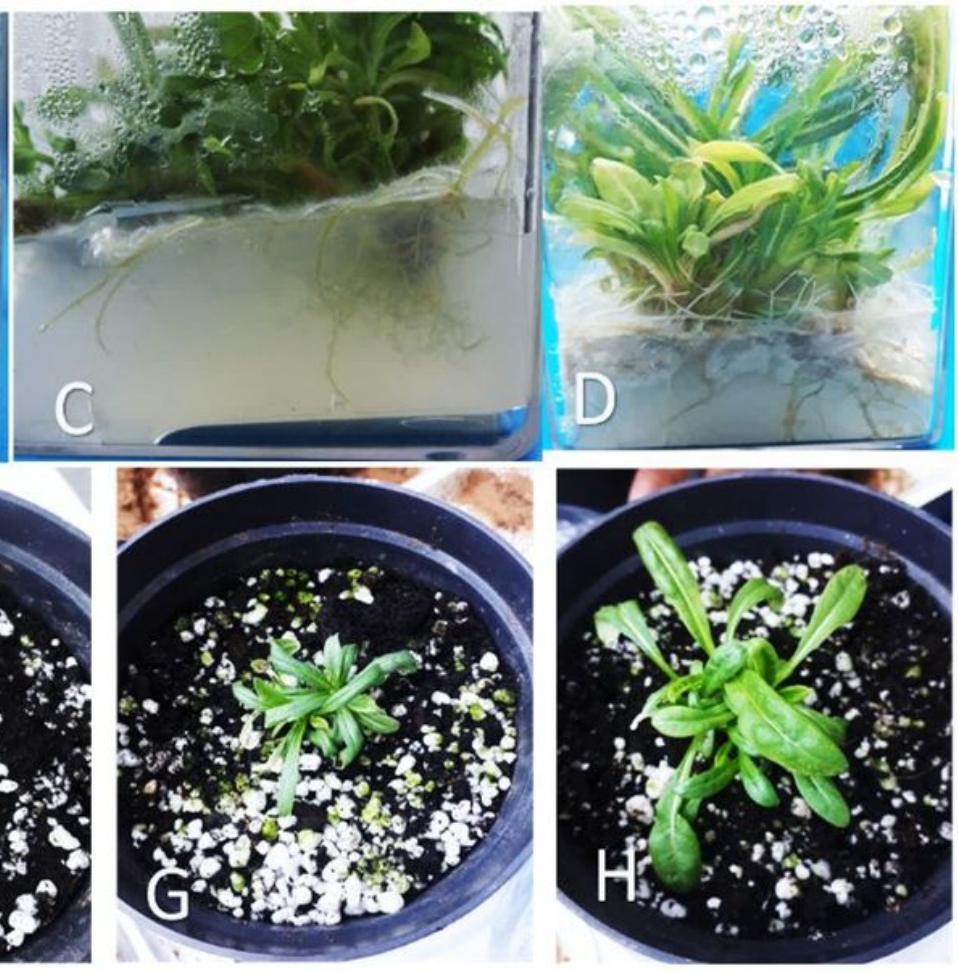

Figure 2

Rooting and acclimatization of Reseda lutea $A$ and $B$ : Rooted plantlet cultured on MS medium containing $0.1 \mathrm{mg} / \mathrm{I}$ of NAA, C: Rooted plantlet cultured on MS medium containing $0.5 \mathrm{mg} / \mathrm{l}$ of NAA, D: Rooted plantlet cultured on MS medium containing $1.5 \mathrm{mg} / \mathrm{I}$ of IBA, E: Rooted plantlet cultured on MS medium containing $0.5 \mathrm{mg} / \mathrm{I}$ of NAA after four weeks, F, G and H: Acclimatized and hardened plant of Reseda lutea. 